\title{
Dispersed Carbon in Basalts of the Altered Oceanic Crust: Isotope Composition and Mechanisms of Formation
}

\author{
V. B. Polyakov ${ }^{a, b}, *$ and S. N. Shilobreeva ${ }^{a, * *}$ \\ ${ }^{a}$ Vernadsky Institute of Geochemistry and Analytical Chemistry (GEOKhI), \\ Russian Academy of Sciences, Moscow, 119991 Russia \\ ${ }^{b}$ Korzhinskii Institute of Experimental Mineralogy (IEM), Russian Academy of Sciences, \\ Chernogolovka, Moscow oblast, 142432 Russia \\ *e-mail:vpolyakov@mail.ru \\ **e-mail:shilobre@mail.ru
}

Received April 30, 2021; revised May 14, 2021; accepted May 15, 2021

\begin{abstract}
Carbon contents and isotopic compositions were compared in the basalt groundmass of the oceanic crust of different age in the zone of the East Pacific Rise. In samples the basalt groundmass of the ancient oceanic crust ( $270 \mathrm{Ma}$, ODP Site $801 \mathrm{C}$ ) in which a carbonate phase was found, the isotopic composition of the oxidized carbon $\left(\delta^{13} \mathrm{C}= \pm 1.5 \% 0\right)$ indicates that this carbon was formed by the precipitation of seawater dissolved inorganic carbon (DIC). In the samples in which no carbonate phase was identified, the low concentration $\left(<0.1 \mathrm{wt} \% \mathrm{CO}_{2}\right)$ of oxidized dispersed carbon and its isotopic composition $\left(\delta^{13} \mathrm{C}<-7 \%\right.$ ) are in the range of values typical of carbon dissolved in basalt glasses without crystallinity. This makes it possible to relate the oxidized dispersed carbon to residual carbon dissolved in the magmatic melt after $\mathrm{CO}_{2}$ degassing. The precipitation of DIC results in a positive correlation between the concentration of total carbon and its $\delta^{13} \mathrm{C}$ values, along with the formation of a carbonate phase. The application of this criterion to basalt groundmass samples of the young crust ( $15 \mathrm{Ma}$, ODP Site $1256 \mathrm{D})$ showed that oxidized dispersed carbon in the young oceanic crust groundmass was not formed by the precipitation of DIC, contradicting the generally accepted paradigm. Constant concentration and $\delta^{13} \mathrm{C}$ values of the reduced dispersed carbon in the basalt groundmass of the young and ancient oceanic crusts, including lithological zones where microbial activity has not been recorded, indicate that the most probable model is high-temperature abiogenic generation of reduced dispersed carbon near the ridge axis. The Fischer-Tropsch synthesis and/or Bell-Boudouard reaction provide a possible basis for the abiogenic model. The Bell-Boudouard reaction $2 \mathrm{CO}=\mathrm{C}+\mathrm{CO}_{2}$ leads to the formation of an adsorbed layer of elemental carbon on the fresh surfaces of minerals during background alteration of the oceanic basalt crust. The $\mathrm{CO}_{2}-\mathrm{CO}$ gas-phase equilibrium maintains the necessary depletion of the newly formed elemental carbon in the ${ }^{13} \mathrm{C}$ isotope to $\delta^{13} \mathrm{C}<-20 \%$. Abiogenic models for the origin of the isotopically light reduced dispersed carbon in the basalt groundmass do not assume the presence of carbon depleted in the heavy ${ }^{13} \mathrm{C}$ isotope in the magmatic melt.
\end{abstract}

Keywords: dispersed carbon, basalts of altered oceanic crust, isotopic composition of carbon, BellBoudouard reaction

DOI: $10.1134 / \mathrm{S} 0869591121060060$

\section{INTRODUCTION}

The origin of carbon dispersed in magmatic and altered rocks as well as its relation to mantle carbon are fundamental problems of the geochemistry of carbon, which cannot be resolved without using isotope data and understanding of the mechanisms that control the isotope composition of dispersed carbon. These problems were actively explored starting with the classic works (Trofimov, 1950, 1952; Craig, 1953; Vinogradov, 1958, 1959; Galimov, 1968) and remain widely debated until nowadays. Dispersed carbon typically occurs in low concentrations (no higher than 1000 ppm
C) and commonly does not form individual carbonbearing phases (with the only possible exception of nanophases). The isotope composition of dispersed carbon in basalts varies within wide limits: $\delta^{13} \mathrm{C}=-30$ to $-3 \%$ o (Galimov, 1968; Sakai et al., 1984; Pineau et al., 2004; Delacour et al., 2008; Alt et al., 2013). Such wide variations in the $\delta^{13} \mathrm{C}$ values of dispersed carbon pose the question of whether the Earth's mantle contains sources of carbon of various isotope composition, with this problem directly interrelated with that of the heterogeneity in the isotope composition of carbon in the Earth's mantle. Elucidation of the origin 
of dispersed carbon and mechanism responsible for its isotope composition is of crucial importance for understanding the geochemical cycles of carbon in the Earth.

Hypotheses explaining the origin of dispersed carbon enriched in the light isotope $\left(\delta^{13} \mathrm{C}<-20 \%\right)$ in intrusive rocks can be classified into two groups. Hypotheses of one of these groups maintain that this is explained by the presence of carbon with low $\delta^{13} \mathrm{C}$ in the Earth's mantle, whereas proponents of the other hypotheses believe that the light isotope composition of dispersed carbon in intrusive rocks was controlled by isotope fractionation processes when the rocks were formed (magma crystallization and degassing, etc.). The former group includes, among others, hypotheses that relate the occurrence of isotopically light dispersed carbon to the relict carbon of meteorites, which was brought to the mantle during the accretion of the Earth (Galimov, 1968); with organic matter during subduction (Cartigny, 2005; Cartigny et al., 2014); and/or processes of Rayleigh distillation when methane was oxidized to $\mathrm{CO}_{2}$ in the mantle (Galimov, 1991). The latter group comprises hypotheses of the reduced dispersed carbon formation by the FischerTropsch-reaction synthesis of organic molecules (Shilobreeva et al., 2011), models of the carbon and/or carbide film formations on newly created mineral surfaces (Tingle and Hochella, 1993; Mathez et al., 2008), and models relating the reduced dispersed carbon formation to bacterial processes (Menez et al., 2012; Alt and Shank, 2011). The mid-1980s witnessed discussion of whether carbon in an atomic state can be hosted in crystals of oxides and major rock-forming minerals. The discussion was triggered by then-newly found evidence that much carbon (up to $1000 \mathrm{ppm}$ ) can be dissolved in the crystal lattices of oxides and silicates (Freund, 1981, 1987; Freund et al., 1977, 1978, 1980; Wengeler et al., 1982; Kathrein et al., 1983). Recently data were recovered that carbon can be dissolved in mantle minerals only in low concentrations, as low as 1-50 ppm (Tingle and Green, 1987; Tingle et al., 1988; Keppler et al., 2003; Ni and Keppler, 2011). Such a significant difference between estimates of the concentrations of dissolved carbon in earlier and later publications by F. Freund and his colleagues seems to be explained by the methodological difficulties, in particular, those related to analyzing contamination carbon. According to the current understanding of the forms of dissolved carbon in silicate minerals, it is hosted in the form of $\mathrm{C}^{4+}$, but not in a reduced mode, when $\mathrm{Si}$ is isomorphically substituted in silicon-oxygen tetrahedrons (Shcheka et al., 2006). Carbon in melts is also dominated by an oxidized form, and reduced carbon can dissolve only at very low $f \mathrm{O}_{2}$, corresponding to the iron-wüstite buffer (Kadik et al., 2004). Based on results in (Freund, 1981; Freund et al., 1977, 1978, 1980; Wengeler et al., 1982; Kathrein et al., 1983), E.M. Galimov (1984) suggested that the enrichment of reduced dispersed carbon in the light ${ }^{12} \mathrm{C}$ isotope is explained by its dissolution in crystals in an atomic zero-valence form, whose $\beta$-factor was assumed to be equal to 1 . This hypothesis is obviously inconsistent with the model of carbon dissolution in mantle minerals in the form of $\mathrm{C}^{4+}$, which is released in the course of analysis in the oxidized component of dispersed carbon.

Intense material exchange between the crust and mantle occurs in the zones of oceanic ridges/rises when the oceanic crust is formed in the process of spreading. Studies of dispersed carbon in oceanic crustal basalts and mechanisms that control the isotope composition of this carbon provides, on the one hand, information on dispersed carbon in the Earth's mantle and, on the other, bridge the gap (or gaps) in understanding the global geochemical cycling of carbon. Thanks to the drilling of oceanic crust conducted over the past few decades, the dataset on concentrations of carbon and its isotope composition in oceanic basalts was significantly augmented, which provided a better insight into physicochemical processes related to alterations of the oceanic crust (e.g., Alt et al., 2003; Früh-Green et al., 2004; Delacour et al., 2008; Shilobreeva et al., 2011). Alterations of the oceanic crust are associated with chemical and mineralogical transformations of carbon-bearing rocks. The total carbon of the altered oceanic crust comprises its oxidized and reduced components, and the origin of these components remains largely uncertain. In the context of studying dispersed carbon, carbon in the basalt groundmass is of key importance, in contrast to carbon concentrated in veinlets, halos, intergranular space, etc., in which it is significantly contaminated. Such samples of crustal rocks of different age have been studied in (Shilobreeva et al., 2011; Martinez et al., 2021). Herein we conduct comparative consideration of the results presented in these publications in the context of the origin of dispersed carbon and probable models of the formation of its isotope composition in basalts in the altered oceanic crust.

\section{SAMPLING PROCEDURES AND EXPERIMENTAL TECHNIQUES}

Samples of basalt groundmass from ODP (Ocean Drilling Program) Holes 1256D and 801C have been studied in (Shilobreeva et al., 2011; Martinez et al., 2021). Hole 1256D (6⒋ $\left.6^{\circ} 0^{\prime} \mathrm{N}, 91^{\circ} 56.10^{\prime} \mathrm{W}\right)$ was drilled through the $\sim 15$-Ma basaltic crust at the eastern slope of the East Pacific Rise. The lithostratigraphy of the altered basaltic crust drilled through by this hole includes (Teagle et al., 2006): (1) a 250-m sequence of sediments, (2) a volcanic (lava) zone at depths of 250 to $1400 \mathrm{~m}$ below the seafloor surface (meters below sea floor, mbsf), a transition zone (1004-1061 mbsf), (4) a layered dike complex, and (5) a plutonic complex (1407-1507 mbsf), which consists of two gabbro bodies 52 and $24 \mathrm{~m}$ thick, with a grano- 
Table 1. Average concentration and isotope composition of total carbon in the basalt groundmass of the young ( $\sim 15 \mathrm{Ma})$ oceanic crust recovered by ODP Hole 1256D (calculated from data in Shilobreeva et al., 2011)

\begin{tabular}{|c|c|c|c|}
\hline \multirow[b]{2}{*}{ Lithological unit } & \multirow[b]{2}{*}{ Thickness, km } & \multicolumn{2}{|c|}{ Hole 1256D } \\
\hline & & $\begin{array}{l}\text { carbon concentration } \\
\left(\mathrm{CO}_{2}, \text { wt } \%\right)\end{array}$ & $\delta^{13} \mathrm{C}, \% \circ$ \\
\hline Volcanic zone & 0.75 & $0.153 \pm 0.062$ & $-23.5 \pm 2.0$ \\
\hline Transition zone & 0.2 & $0.237 \pm 0.010$ & $-23.6 \pm 1.0$ \\
\hline Dike zone & 1.2 & $0.129 \pm 0.073$ & $-20.9 \pm 2.6$ \\
\hline Gabbro & 0.1 & $0.076 \pm 0.013$ & $-20.8 \pm 0.5$ \\
\hline Vertical section as a whole & 2.25 & $0.144 \pm 0.061$ & $-22.2 \pm 2.1$ \\
\hline
\end{tabular}

blastic dike $24 \mathrm{~m}$ thick in between. The lower gabbro body has not been drilled throughout its whole thickness.

Hole $801 \mathrm{C}\left(18^{\circ} 38.538^{\prime} \mathrm{N}, 156^{\circ} 21.588^{\prime}\right.$ E) was drilled into the basaltic oceanic crust dated at $270 \mathrm{Ma}$ in the West Pacific, in the Pigafetta Basin. The water depth at this site is $5674 \mathrm{~m}$, and the hole penetrated the sedimentary cover $(461.6 \mathrm{~m})$ and $474 \mathrm{~m}$ of volcanic (lava) zone of the crystalline basement. The lithostratigraphy of Hole $801 \mathrm{C}$ was studied in much detail (Lancelot et al., 1990; Plank et al., 2000; Alt and Teagle, 2003). The drilled-through basaltic basement was subdivided into eight volcanic units (blocks), which were counted downward from the boundary between the sediments and basaltic basement. Block I is $60.2 \mathrm{~m}$ of basalt sills dated at 157 Ma. Blocks II and V are hydrothermal rocks enriched in $\mathrm{Si}$ and Fe. Block II (10-20 m thick) separates the alkaline and tholeiite basalts, and block V (1 m thick) occurs within the basaltic basement at a depth of $150 \mathrm{~m}$ from its upper boundary. The drilled-through $400-\mathrm{m}$ sequence of tholeiite basalts consists of massive, layered, and pillow lavas (blocks III, IV, VI, and VIII) and includes a $10-\mathrm{m}$ layer of breccia at a depth of $360 \mathrm{~m}$ from the upper boundary of the basaltic basement. The lithology of the volcanic portion of the basaltic basement penetrated by Hole $801 \mathrm{C}$ is typical of the oceanic crust, except that it includes younger alkaline basalts (block I), which were produced off the axis of the rise, and hydrothermal rocks (blocks II and V), which were formed by flows of low-temperature hydrothermal fluids immediately on the spreading axis (Alt and Teagle, 2003; Alt, 2003). The average porosity of the basalts is $11 \pm 4 \%$ to a depth of $300 \mathrm{~m}$ from the basaltic basement and is $7 \pm 1 \%$ at greater depths (Jarrard et al., 2003). We assumed that the basaltic basement to depths of less than $300 \mathrm{~m}$ corresponds to the Upper Volcanic Zone (UVZ), whereas the lower drilledthrough part of the basement can be referred to as the Lower Volcanic Zone (LVZ).

We have studied nineteen samples from Hole 1256D. Their characteristics are listed in Tables 1 and 2 in (Shilobreeva et al., 2011). The samples were collected from all lithological zones of the basaltic base- ment penetrated by this hole. The eleven studied samples from Hole $801 \mathrm{C}$ represent tholeiites from depths lower than $143.5 \mathrm{~m}$ from the upper boundary of the basement (Table 1 in Martinez et al., 2021), six samples from this hole were recovered from the UVZ, and five were from LVZ (Table 1 in Martinez et al., 2021). In samples from Holes 1256D and 801C, the material of veinlets, halos, and domains with cavities was carefully separated from the basalt groundmass. The studies were focused mostly on samples of the groundmass, although carbon and oxygen isotope compositions were also sometimes analyzed in the veins for comparison (Shilobreeva et al., 2011; Martinez et al., 2021).

The methods applied in studying samples from Hole 1256D and 801C were different. Samples from Hole $1256 \mathrm{D}$ were successively subjected to thermal treatment (1) at $100^{\circ} \mathrm{C}$ in vacuum for $1 \mathrm{~h}$ to get rid of surface contaminants, (2) at $250^{\circ} \mathrm{C}$ for $1 \mathrm{~h}$ at an oxygen partial pressure of 4 mbar to oxidize and remove organic compounds, (3) at $900^{\circ} \mathrm{C}$ for $1 \mathrm{~h}$ at an oxygen partial pressure of $\sim 5 \times 10^{-4}$ mbar; (4) at $1170^{\circ} \mathrm{C}$ for $1 \mathrm{~h}$ at an oxygen partial pressure of $\sim 5 \times 10^{-4}$ mbar; and (5) at $1170^{\circ} \mathrm{C}$ for $30 \mathrm{~min}$ at an oxygen partial pressure of 4 mbar (Shilobreeva et al., 2011). The released gases $\left(\mathrm{CO}_{2}\right.$ and $\left.\mathrm{H}_{2} \mathrm{O}\right)$ were frozen out, their amounts were measured, and their carbon and oxygen isotope compositions were analyzed. The total content and isotope composition of carbon released at temperatures of 900 and $1170^{\circ} \mathrm{C}$ were assumed to be the total content of carbon in the basalt groundmass (Shilobreeva et al., 2011). This method did not allow us to separate the oxidized and reduced carbon.

Samples from Hole 801C were analyzed in compliance with a recently designed procedure (Martinez et al., 2021). The samples were crushed to $<150 \mu \mathrm{m}$, heated at $100^{\circ} \mathrm{C}$ in vacuum for $1 \mathrm{~h}$, and then each of the samples was subdivided into three portions. One of them was used to measure the total content and isotope composition of carbon in the sample. This was done by heating no less than $100 \mathrm{mg}$ of the sample at a temperature of $1100^{\circ} \mathrm{C}$ for $1 \mathrm{~h}$ at an oxygen pressure of 4 mbar. This procedure resulted in that all of the released carbon was oxidized to $\mathrm{CO}_{2}$, whose amount 
and isotope composition were measured as described in (Javoy and Pineau, 1991). The inaccuracies of the measurements were $5 \%$ and $0.2 \%$, respectively. The released hydrogen was also oxidized to $\mathrm{H}_{2} \mathrm{O}$, and then its amount and isotope composition were measured (the hydrogen isotope composition was measured accurate to $\sim 2 \%$ ). The second portion of the sample was utilized to measure the isotope composition of the reduced carbon. To do this, the material was preparatorily treated with $6 \mathrm{~N} \mathrm{HCl}$ to remove the oxidized carbon component. After the treatment, this portion of the sample was washed with $\mathrm{CO}_{2}$-free deionized water and then dried at $50^{\circ} \mathrm{C}$ for one week. The material was then thermally processed, and the amount of the released $\mathrm{CO}_{2}$ and its carbon isotope composition were measured in a manner analogous to what was done with the first portion of the sample. The third portion of the sample was used to measure the amount and isotope composition of the oxidized part of the carbon. The portion was treated with phosphoric acid according to the procedure in (McCrea, 1950). This procedure was carried out at room $\left(25^{\circ} \mathrm{C}\right)$ and elevated $\left(80^{\circ} \mathrm{C}\right)$ temperatures. At room temperature, it was $\mathrm{CaCO}_{3}$ to preferably decompose, whereas other carbonates $\left[(\mathrm{Ca}, \mathrm{Mg}, \mathrm{Fe}) \mathrm{CO}_{3}\right]$ were decomposed at the elevated temperature. The analytical inaccuracies were $\pm 0.1 \%$ or for $\delta^{13} \mathrm{C}$ and $\pm 0.5 \%$ o for $\delta^{18} \mathrm{O}$. The relative inaccuracy of the determined concentration of the oxidized component was $10 \%$. The reader can find a detailed description of the procedures in (Martinez et al., 2021).

\section{COMPARISON OF THE RESULTS ON HOLES 801C AND 1256D AND THEIR DISCUSSION}

Figure 1 shows how the content of carbon and its isotope composition depend on depth in the basalt basement along Holes $801 \mathrm{C}$ and $1256 \mathrm{D}$, according to data in (Martinez et al., 2021; Shilobreeva et al., 2011). Obviously, the profiles of Holes $801 \mathrm{C}$ and $1256 \mathrm{D}$ are different. Samples of basalt groundmass from Hole 801C in which a carbonate phase was identified and which were recovered mostly from UVZ are characterized by relatively high concentrations of carbon and its enrichment in the heavy ${ }^{34} \mathrm{C}$ isotope. Samples from Holes $801 \mathrm{C}$ and $1256 \mathrm{D}$ in which no carbonate was found bear low carbon concentrations and have low $\delta^{13} \mathrm{C}<$ $-15 \%$ o (Figs. 1a, 1b). According to the carbon contents and the absence of identifiable carbonate phases, these samples shall be viewed as dispersed carbon. A deeper insight into the nature of the dispersed carbon can be gained by analyzing data obtained on the oxidized and reduced carbon components in basalt groundmass samples from Hole 801C.

\section{Oxidized Component of Dispersed Carbon in Basalts in the Altered Oceanic Crust}

The aforementioned procedure applied in analysis of samples from Hole 801C (Martinez et al., 2021) provides much more information than the procedure used in analysis of material from Hole 1256D (Shilobreeva et al., 2011) and enables one to understand the origin and behavior of carbon in basalts of the altered oceanic crust. Figure 2 shows profiles of the concentration and isotope composition of the oxidized and reduced carbon components in samples from Hole 801C. This figure also shows, for comparison, the concentration and isotope composition of carbon in the veins. Figure 2 demonstrates that the profiles of these components are different. The oxidized component in samples with an identified carbonate phase shows an obvious trend in carbon concentration and $\delta^{13} \mathrm{C}$ values with depth. At the same time, the samples in which no such phase was found display no correlations of these parameters with depth in the basaltic basement. It is also worth mentioning that the isotope compositions of the oxidized carbon in the groundmass samples containing and not containing a carbonate phase are notably different. While the $\delta^{13} \mathrm{C}$ values $(-0.4$ to $+1.5 \%$ ) for the oxidized component of the samples in which a carbonate phase was found lie within the same range of $\delta^{13} \mathrm{C}$ values as that of the oxidized carbon in the carbonate veins (Fig. 2) and are typical of the carbon isotope composition of calcite precipitated from seawater (Hoefs, 2018), the carbon isotope composition of the oxidized dispersed carbon in the samples without carbonate phase $\left(\delta^{13} \mathrm{C}=-7.1\right.$ to $-10.7 \%$ ) cannot be explained by the precipitation of carbonate carbon (Fig. 3). Such low $\delta^{13} \mathrm{C}$ values of carbonate carbon have been previously found in the veins at depth of less than $260 \mathrm{~m}$ from the contact between the sedimentary layer and basement and were explained by the oxidation of organic carbon (Alt and Teagle, 2003). However, all of our samples of basalt groundmass with oxidized carbon showing low $\delta^{13} \mathrm{C}$ values were recovered from greater depths. The $\delta^{13} \mathrm{C}$ values of oxidized carbon in the silicate veins coincide (within the analytical errors) with the corresponding values for oxidized dispersed carbon in the basalt groundmass. To elucidate the genesis of oxidized carbon in the basalt groundmass, we compared data on the carbon isotopic composition and concentrations in samples from Hole 801C (Figs. 2a, 2b; Martinez et al., 2021) with corresponding data on the basalt glasses (Fig. 3). As seen in Fig. 3, the concentration and isotope composition of oxidized carbon in the basalt groundmass of samples from Hole 801C (Martinez, 2021) in which no carbonate phase was found lie within the same ranges as the values for basalt glasses from mid-oceanic ridges, oceanic islands, island arcs, and active continental margins (Des Marais and Moore, 1984; Mattey et al., 1984; 1989; Sakai et al., 1984; Blank et al., 1993; Pineau et al., 2004; Aubaud et al., 2004). The $\delta^{13} \mathrm{C}$ values 


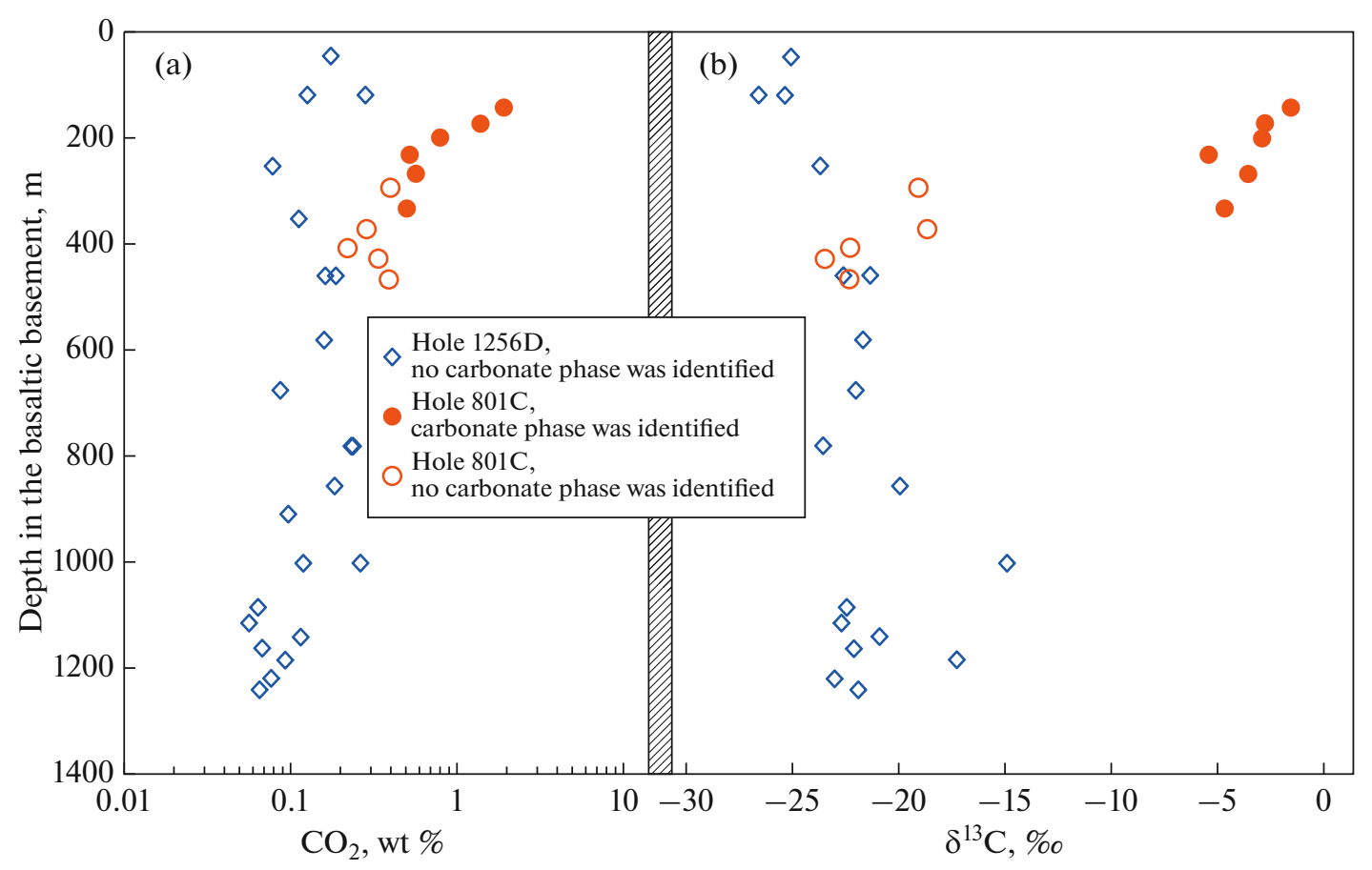

Fig. 1. Dependence of the total carbon concentration and isotope composition on the sampling depth of the basalt groundmass of the altered oceanic crust, according to data in (Martinez et al., 2021; Shilobreeva et al., 2011). The samples were recovered by Hole $801 \mathrm{C}$, which was drilled through the ancient ( $\sim 270 \mathrm{Ma})$ oceanic crust, and Hole $1256 \mathrm{D}$, drilled through the young ( $\sim 15 \mathrm{Ma}) \mathrm{crust}$. Carbon concentration and $\delta^{13} \mathrm{C}$ values are given for basalt groundmass samples in which a carbonate phase was (solid symbols) and was not (open symbols) identified. The total carbon concentration and isotope composition in samples without carbonate phase lie within the ranges of the values of the young and ancient oceanic crust. Samples with an identified carbonate phase show systematic variations in the values with depth.

of dispersed carbon from silicate veins recovered by Hole $801 \mathrm{C}$ plot within the same region in the diagram carbon concentration vs. carbon isotope composition (Fig. 3). This indicates that dispersed carbon in these rocks is of the same genesis. Dispersed carbon dissolved in the basalt glasses is residual magmatic carbon, which was retained in the magmatic melt in the form of $\mathrm{CO}_{3}^{2-}$ groups after $\mathrm{CO}_{2}$ degassing (Javoy et al., 1982; Pineau et al., 2004).

Samples of basalt groundmass from Hole 801C thus contain oxidized carbon of two types: (1) carbon that precipitated in the form of a carbonate phase from seawater and (2) residual (after $\mathrm{CO}_{2}$ degassing) magmatic carbon that does not form any individual phase. It is the latter carbon that can be considered as dispersed one. The former carbon is mainly timed to UVZ (depths of less than $300 \mathrm{~m}$ from the basement top), and its source is seawater dissolved inorganic carbon (DIC). In the currently accepted assumed paradigm, it is this carbon that is the only source of oxidized carbon in samples of the altered basaltic crust (e.g., Delacour et al., 2008; Shilobreeva et al., 2011; Alt et al., 2013). Obviously, the different concentrations and isotope compositions of oxidized carbon in $\mathrm{UVZ}$ and LVZ at low variations in the reduced carbon (Fig. 2) control the variations in the concentration and isotope composition of total carbon with depth in Hole 801C (Fig. 1). Carbonate precipitation from seawater results in a correlation between the isotope composition of the total carbon and its concentration (Fig. 4). For example, the samples from Hole $801 \mathrm{C}$ in which DIC precipitated as carbonates show a positive correlation between the total carbon concentration and its isotope composition (the correlation coefficient $R=$ 0.862). Conversely, any appreciable correlation between the total carbon concentration and its isotope composition $(R=0.124)$ is not exhibited in samples, which contain oxidized carbon as residual magmatic carbon and a carbonate phase. Hence, the incorporation of carbonate carbon precipitating from seawater in the basalt groundmass during alterations of the basaltic oceanic crust results in that the groundmass contains a newly formed carbonate phase and shows a correlation between the total carbon concentration and its isotope composition. Applying these criteria to basalt groundmass samples from Hole 1256D (Fig. 4) studied in (Shilobreeva et al., 2011), in which neither a carbonate phase nor any correlations between the total carbon concentration and its isotope composition $(R=0.100)$ were observed, led us to admit that no appreciable infiltration of carbonate carbon from seawater into the basalt groundmass could take place. This conclusion is consistent with data acquired by 


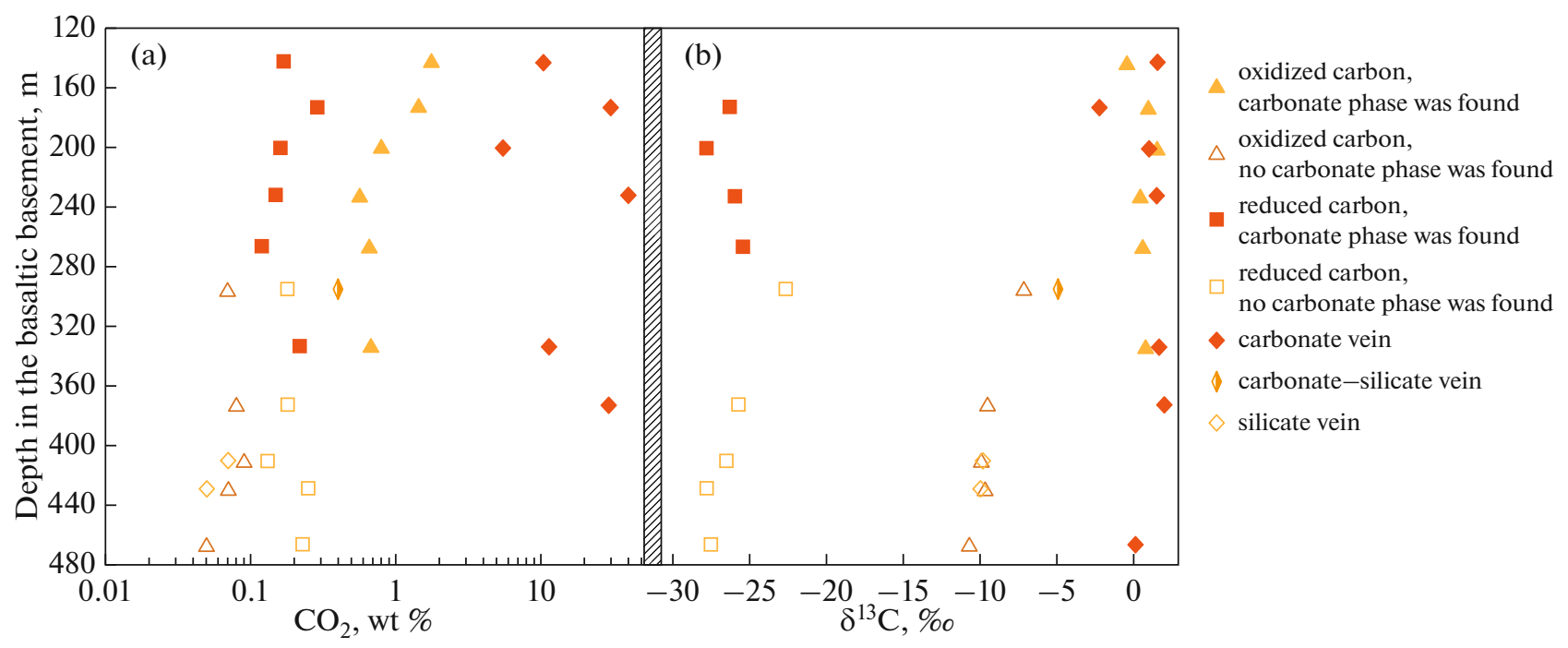

Fig. 2. (a) Dependence of the concentrations and (b) isotope composition of oxidized and reduced carbon on the sampling depth of the basalt groundmass of the altered oceanic crust (Hole 801C), according to data in (Martinez et al., 2021). Samples of basalt groundmass in which a carbonate phase was identified (solid triangles) differ from samples in which no such phase was found (open triangles) not only in oxidized carbon concentration but also in its isotope composition. The isotope composition of oxidized carbon in samples of basalt groundmass with a carbonate phase lies within the same range of values as the oxidized carbon isotope composition in the carbonate veins (solid rhombs). The concentration and isotope composition of oxidized carbon in groundmass samples without carbonate phase coincide (within the analytical inaccuracies) with those of oxidized carbon in the silicate veins (open rhombs). The sample in which both silicate and carbonate veins were found shows intermediate concentration and $\delta^{13} \mathrm{C}$ values. The concentration and isotope composition of the reduced carbon in the basalt groundmass (solid and open squares) do not any significantly vary with depth and are not correlated with the presence or absence of a carbonate phase.

studying sample 123 (Table 4 in Shilobreeva et al., 2011), with the application of methods analogous to those used to study samples from Hole 801C (Martinez et al., 2021). The oxidized carbon concentration in this sample is 0.039 wt $\% \mathrm{CO}_{2}$, and $\delta^{13} \mathrm{C}=-15.2 \%$, and these values are principally different from those for oxidized carbon in sample 149 , which contains calcite $\left(6.7 \mathrm{wt} \% \mathrm{CO}_{2} ; \delta^{13} \mathrm{C}=-4.5 \%\right.$ ), with data on this sample also presented in (Table 4 in Shilobreeva et al., 2011). Analysis of the genesis of the oxidized carbon casts doubt onto the currently commonly accepted paradigm that the oxidized carbon component in basalts in the altered oceanic crust consists solely and exclusively of carbon that precipitated from seawater.

\section{Reduced Component of Dispersed Carbon in Basalts in the Altered Oceanic Crust}

In contrast to what is typical of the oxidized carbon, the variations in the concentration and isotope composition of reduced carbon in the basalt groundmass of Hole $801 \mathrm{C}$ are insignificant (Fig. 2). The average values of these parameters in UVZ $(0.18 \pm 0.07 \mathrm{wt} \%$ $\mathrm{CO}_{2} ; \delta^{13} \mathrm{C}=-25.7 \pm 1.7 \%$ ) and $\mathrm{LVZ}(0.20 \pm 0.05 \mathrm{wt} \%$ $\mathrm{CO}_{2} ; \delta^{13} \mathrm{C}=-27.0 \pm 0.9 \%$ ) are undistinguishable within the inaccuracies (Martinez et al., 2021). For Hole 1256D, data on the total carbon are available and are also very little variable throughout the whole vertical section (Fig. 1). With regard to that reduced carbon dominates over oxidized one in the basalt groundmass of samples from Hole 1256D (Shilobreeva et al., 2011), it is reasonable to conclude that the variations in the concentration and isotope composition of the reduced carbon are also small. ${ }^{1}$

The possible sources of the reduced carbon may have been (1) dissolved organic carbon brought by seawater; (2) carbon resulting from microbial activity, including the bacteria themselves; and (3) reduced carbon produced by abiogenic processes. The constancy of the concentrations and isotope compositions of reduced carbon in the basalt groundmass over the whole vertical section of Holes $801 \mathrm{C}$ and $1256 \mathrm{D}$ provides evidence that carbon in each of the holes came from the same source. As follows from numerical evaluations in (Martinez et al., 2021), the carbon concentration in samples from Hole $801 \mathrm{C}\left(\mathrm{CO}_{2}=0.19 \pm\right.$ $0.06 \mathrm{wt} \%$ on average) may have been reached at a high $(>860)$ water/rock ratio, which remained constant throughout the whole vertical section of this hole. However, as numerical estimates evidence (Martinez

\footnotetext{
${ }^{1}$ The dominance of reduced carbon in the samples is consistent with the total carbon isotope composition and the concentration of oxidized carbon in sample 123, in which oxidized carbon makes up $4.5 \%$ of the total carbon concentration (Shilobreeva et al., 2011). This is also consistent with our analysis in the previous section, according to which oxidized dispersed carbon in the basalt groundmass from Hole $1256 \mathrm{D}$ is residual (after $\mathrm{CO}_{2}$ degassing) carbon dissolved in the magmatic melt, and its concentration is lower than $0.1 \mathrm{wt} \% \mathrm{CO}_{2}$.
} 


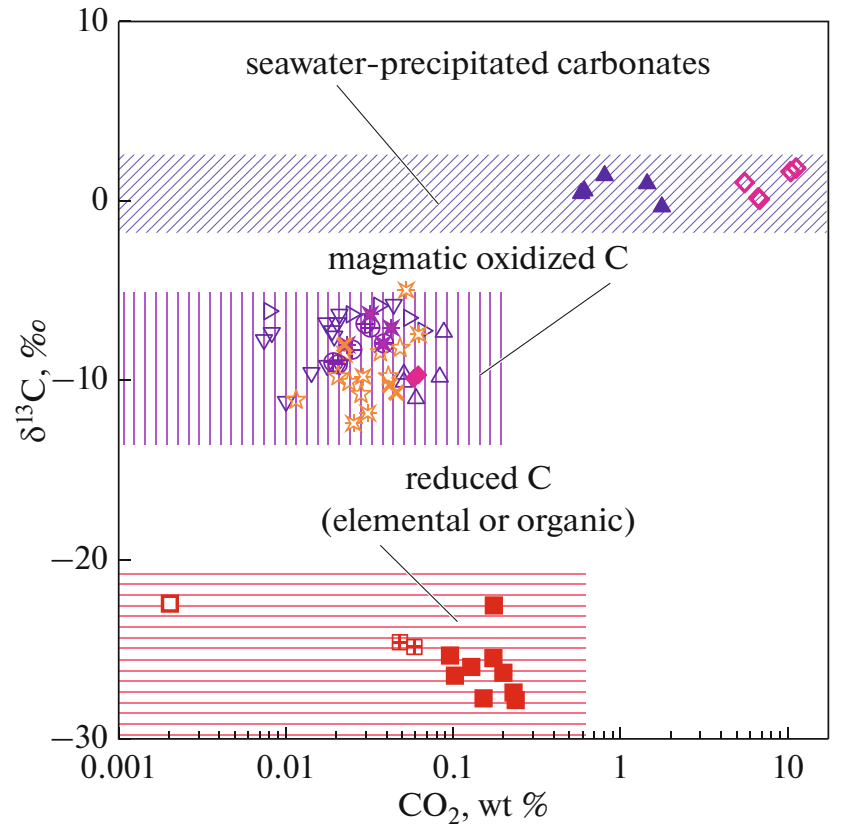

- reduced C (Martinez et al., 2021)

oxidized $\mathrm{C}$ in samples with a carbonate phase

- Martinez et al., 2021)

$\triangle \quad$ ooxidized $\mathrm{C}$ in samples without carbonate phase (Martinez et al., 2021)

oxidized $\mathrm{C}$ in the carbonate veins

(Martinez et al., 2021)

oxidized $\mathrm{C}$ in the silicate veins

- (Martinez et al., 2021)

$\nabla \quad$ C dissolved in glasses without crystallinity

$\nabla \quad$ (Pineau et al., 2004)

․ C in aphyric samples (Pineau et al., 2004)

$\mathrm{C}$ dissolved in glasses without crystallinity

(Sakai et al., 1984)

C in crypto- and microcrystalline samples

田 (Sakai et al., 1984)

C dissolved in glasses with crystallinity $<1$ vol \%

(Aubaud et al., 2004)

$\mathrm{C}$ dissolved in basalt glasses

(Mattey et al., 1984)

$\mathrm{C}$ dissolved in basalt glasses

(Mattey et al., 1989)

C dissolved in basalt glasses

* (Da Marais and Moore, 1984)

( C dissolved in basalt glasses

$\oplus \quad$ (Blank et al., 1993)

Fig. 3. Analysis of the genesis of oxidized and reduced carbon in samples (Hole 801C) of the basalt groundmass of the ancient altered oceanic crust (the figure was modified from Martinez et al., 2021). The $\delta^{13} \mathrm{C}$ values of the oxidized carbon in groundmass samples with a carbonate phase correspond to the range typical for seawater DIC precipitated as carbonates, which is also typical of the oxidized carbon of the carbonate veins. Oxidized carbon in groundmass samples without carbonate phase yields values in the range typical of the concentration and $\delta^{13} \mathrm{C}$ values of carbon dissolved in basalt glasses, which suggests their derivation from a common source. This range is also typical of oxidized carbon in the silicate veins. The $\delta^{13} \mathrm{C}$ values of the reduced carbon occur within the same range as those of the carbon of organic compounds of biogenic or abiogenic genesis (Fischer-Tropsch synthesis). The concentration and isotope composition values of carbon in the crypto- and microcrystalline glasses also lie within this range. This provides an argument that the reduced elemental carbon was formed on the freshly produced surfaces of minerals according to the Bell-Boudouard reaction (see text).

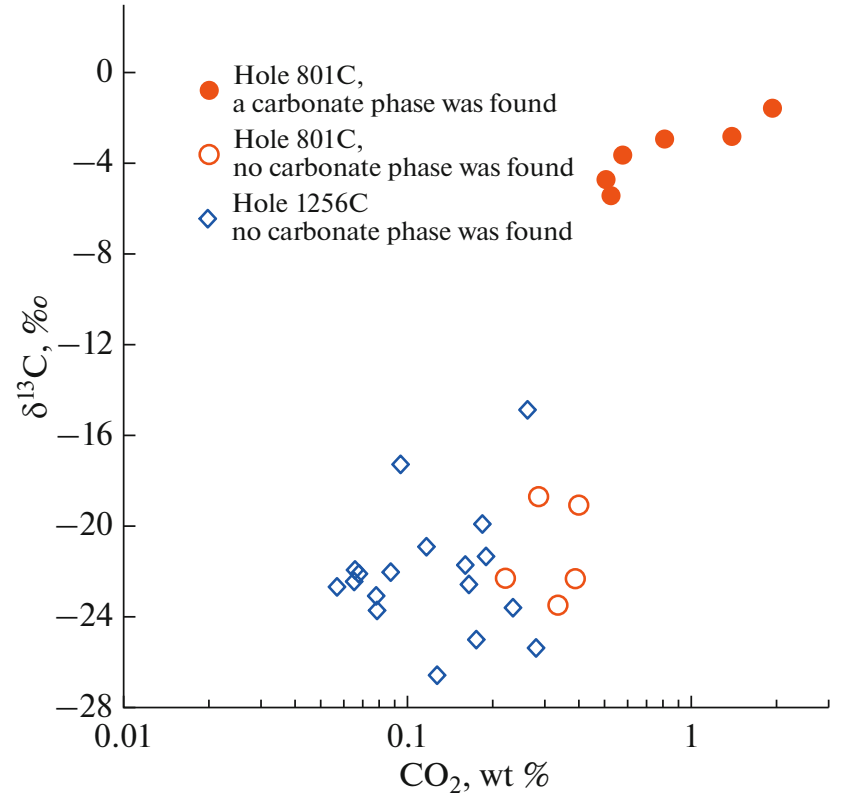

Fig. 4. Analysis of data on total carbon in basalt groundmass samples of the altered oceanic crust. Basalt groundmass samples in which a carbonate phase was found (solid circles) show a clearly discernible positive correlation between the carbon concentration and its $\delta^{13} \mathrm{C}$ (correlation coefficient $R=0.862$ ), whereas samples without carbonate phase show no such correlation. The occurrence of a carbonate phase and a positive correlation between the total carbon concentration and its isotope composition may serve as a criterion of that oxidized carbon in the basalt groundmass was formed by the precipitation of carbonates from seawater.

et al., 2021), this is inconsistent with the large variations in water flows through various zones of the basaltic basement (Alt and Teagle, 2003). It is this fact that indicates that the reduced carbon could hardly be formed in the basalt groundmass of samples from Hole $801 \mathrm{C}$ by the infiltration of organic carbon dissolved in seawater (Martinez et al., 2021). Analogous considerations and reasoning based on the constancy of reduced carbon concentration in the vertical section of Hole $1256 \mathrm{D}$ led us to rule out seawater-dissolved organic carbon from the list of candidates for the probable sources of reduced dispersed carbon in basalt groundmass samples from Hole 1256D (Shilobreeva et al., 2011).

The nature of the microbial component of reduced carbon in the basalt groundmass samples deserves closer inspection. Microbial activity in the samples from Hole $1256 \mathrm{D}$ was evaluated from the sulfur isotope composition $\left(\delta^{33} S\right.$ and $\left.\delta^{34} S\right)$ of the secondary sulfides that were formed in the course of the alterations of the continental crust (Rouxel et al., 2008). Based on the facts that sulfur resulting from bacterial sulfate reduction is characterized by low $\delta^{34} \mathrm{~S}$ values $(<-30 \%$ ), whereas $\delta^{34} \mathrm{~S}$ of the primary sulfur in basalts is about $0 \%$, these authors arrived at the conclusion that bac- 
terial sulfate reduction operated throughout the whole vertical section of Hole $801 \mathrm{C}$, even at the depth of basaltic basement $(340 \mathrm{~m})$. In analyzing samples of the basalt groundmass analogous to the samples from Hole $801 \mathrm{C}$ in which reduced carbon concentrations and isotope composition were measured (Martinez et al., 2021), it should be noted that the pyrite has $\delta^{34} S_{\text {ave }}=-27.1 \pm 16.3 \%$ at depth levels in the basaltic basement shallower than $260 \mathrm{~m}$, whereas pyrite from depths greater than $260 \mathrm{~m}$ has $\delta^{34} \mathrm{~S}_{\mathrm{cp}}=-5.1 \pm 4.4 \% o .^{2}$ Thus, the microbial activity calculated from the sulfur isotope composition of pyrite in the basalt groundmass samples decreases with depth. Inasmuch as the reduced carbon isotope composition therewith remained practically unchanging, it is reasonable to believe that microbial carbon could not be an important source of reduced carbon in the basalt groundmass samples from Hole 801C. This conclusion is even more obvious for Hole 1256D. Samples from this hole were also analyzed for sulfur isotope composition, and these data indicate that microbial activity is distinguishable only in the volcanic portion of the vertical section and faded off starting from the boundary between the volcanic and transition zones at a depth of $750 \mathrm{~m}$ in the basaltic basement (Alt and Shank, 2011). The total carbon concentration in the basalt groundmass in the volcanic zone $\left(0.153 \pm 0.062 \mathrm{wt} \% \mathrm{CO}_{2}\right)$ coincides, with regard to the uncertainties, with the carbon concentration $\left(0.142 \pm 0.077 \mathrm{wt} \% \mathrm{CO}_{2}\right)$ in the underlying transition and dike zones (Shilobreeva et al., 2011). Because total carbon in the basalt groundmass is dominated by the reduced component, the approximate equality of the concentrations in the $750-\mathrm{m}$ volcanic zone and the underlying 400-m transition + dike zones of the basaltic basement convincingly testifies that the microbial component did not any significantly contribute to reduced carbon in samples from Hole 1256D.

The constancy of concentrations and isotope compositions of carbon from Hole 1256D is in good agreement with the model of the origin of reduced carbon near the ridge axis at relatively high temperatures (Shilobreeva et al., 2011), with abiogenic synthesis of reduced carbon being suitable for this model. The abiogenic generation of reduced carbon is commonly considered based on the Fischer-Tropsch process (Shock and Schulte, 1998; Seewald et al., 2006; McCollom and Seewald, 2007) ${ }^{3}$

$$
\mathrm{CO}_{2}+\mathrm{H}_{2}=\mathrm{CO}+\mathrm{H}_{2} \mathrm{O}
$$

\footnotetext{
2 This value involves results on pyrite recovered from the vicinities of cavities a few millimeters across. These samples were rejected preparatorily to analysis for the carbon isotope composition. Removing them $\delta^{34} \mathrm{~S}_{\mathrm{ave}}$ becomes even closer to the mantle values.

${ }^{3}$ The resultant reaction is written in the form $\mathrm{CO}_{2}+4 \mathrm{H}_{2}=\mathrm{CH}_{4}+$ $2 \mathrm{H}_{2} \mathrm{O}$ or $\mathrm{CO}_{2}+\mathrm{H}_{2} \rightarrow \mathrm{CH}_{4}+\mathrm{C}_{2} \mathrm{H}_{6}+\mathrm{C}_{3} \mathrm{H}_{8}+\mathrm{C}_{n} \mathrm{H}_{n+2}+$ $\mathrm{H}_{2} \mathrm{O}$.
}

PETROLOGY Vol.29 No.6 2021

PETROLOGY Vol. 29, No. 6 , 2021

$$
\mathrm{CO}+3 \mathrm{H}_{2} \rightarrow \mathrm{CH}_{4}+\mathrm{H}_{2} \mathrm{O} \text {. }
$$

These reactions at the QFM (quartz-fayalite-magnetite) buffer are thermodynamically permissible to a temperature of $400^{\circ} \mathrm{C}$ (McCollom and Seewald, 2007; McCollom and Bach, 2009) and reach the maximum intensity at temperatures of $<250-300^{\circ} \mathrm{C}$ (Shock, 1990; Rhusdi and Simoneit 2001). The FischerTropsch reactions (1a and $1 \mathrm{~b})$ are associated with a significant isotopic effect and lead to enrichment of the synthesized hydrocarbons in the light isotope (McCollom and Seewald, 2006; Taran et al., 2007, 2010) up to $\delta^{13} \mathrm{C}<-20 \%$ o, i.e., values determined for reduced carbon (Delacour et al., 2008; Shilobreeva et al., 2011; Martinez et al., 2021). However, the efficiency of the Fischer-Tropsch process at elevated temperatures $\left(>350^{\circ} \mathrm{C}\right)$, which are typical of the dike and plutonic (gabbro) zones of Hole 1256D (Alt et al., 2010), seems not to be high. Moreover, the efficiency of the Fischer-Tropsch reaction decreases in the presence of water even at low $\mathrm{CO}_{2} / \mathrm{CO}$ ratios (Shock, 1990; Shock and Schutle, 1998; McCollom and Seewald, 2006, 2007).

Another mechanism of the reduced carbon formation based on the Bell-Boudouard reaction, $2 \mathrm{CO} \rightarrow \mathrm{C}$ $+\mathrm{CO}_{2}$, was intensively studied both experimentally and theoretically (Mathez and Delaney, 1981; Mathez, 1984, 1987; Pineau and Mathez, 1990; Mathez and Mogk, 1998). It was demonstrated that this mechanism results in reduced carbonaceous matter (graphite and other forms of elementary carbon, carbines, etc.) on the newly formed surfaces of minerals and pore walls, which act as catalysts of the Bell-Boudouard reaction (Mathez and Delaney, 1981). In this instance, the Bell-Boudouard reaction can be written as (Mathez and Delaney, 1981)

$$
\mathrm{CO}^{\mathrm{ad}}+\mathrm{CO}^{\mathrm{v}} \rightarrow \mathrm{C}^{\mathrm{ad}}+\mathrm{CO}_{2}^{\mathrm{v}},
$$

in which the ad and $\mathrm{v}$ indices denote the reactants and reaction products that are adsorbed on the surface and occur in the gas phase, respectively. This reaction is shifted to the synthesis of the products at temperatures below $950^{\circ} \mathrm{C}$ and may proceed simultaneously with the Fischer-Tropsch reactions, with water (if present) shifting reactions (1a) and (1b) to their left-hand sides, which makes reaction (2) more probable (Lapidus et al., 2011).

In spite of the convincingness of evidence that elemental carbon does occur in the rocks and the corresponding microphotographs presented in (Mathez and Delaney, 1981), the mechanism that forms reduced carbon in the basalt groundmass has not received broad acknowledgment. This is likely due to difficulties in explanation of elemental carbon depletion in ${ }^{13} \mathrm{C}$ isotope up to $\delta^{13} \mathrm{C}<-20 \%$ in the framework of the model of equilibrium isotope fractionation. Indeed, equilibrium fractionation between graphite and $\mathrm{CO}_{2}$ does not exceed 14\%o (Fig. 5) and cannot be responsible for the observed isotope com- 
position of reduced carbon in the basalt groundmass samples from Holes 801C and 1256D (Shilobreeva et al., 2011; Martinez et al., 2021). To bypass this difficulty, a multistage mechanism was proposed, with the isotope effects multiplied at each stage (Pineau and Mathez, 1990). However, this mechanism cannot be considered realistic. Meanwhile, analysis of the various mechanisms of the Bell-Boudouard reaction (2), with regard to the temperature, chemical composition, and structure of the catalytic surfaces, the occurrence of admixtures and water vapor in the gas phase, etc. (Haas et al., 1968; Turkdogan and Vinters, 1974; Olsson and Turkdogan, 1974; Renshaw et al., 1970; Tsao et al., 1977; Lapidus et al., 2011), indicates that all of them involve a stage when $\mathrm{CO}$ is formed in equilibrium with $\mathrm{CO}_{2}$, the adsorption of the newly formed $\mathrm{CO}$ on a catalytic surface, and an irreversible stage of the disproportionation of the adsorbed $\mathrm{CO}$ into elementary carbon (graphite) and $\mathrm{CO}_{2}$ by the Bell-Boudouard reaction (2). It is therewith important to mention that graphite is an extremely inert material in terms of isotope exchange, which practically does not proceed between graphite and $\mathrm{CO}_{2}$ at temperatures below $600^{\circ} \mathrm{C}$ (Kitchen and Valley, 1995; Polyakov and Kharlashina, 1995; Deines and Eggler, 2009). This principal scenario for the origin of the isotope composition of carbon based on the BellBoudouard reaction ensures the depletion of the newly formed reduced carbon in the ${ }^{13} \mathrm{C}$ isotope. Indeed, literature data indicate that the coefficient of equilibrium fractionation between $\mathrm{CO}_{2}$ and $\mathrm{CO}$ is much greater than that between $\mathrm{CO}_{2}$ and graphite (Bottinga, 1969; Richet et al., 1977; Chacko et al., 1991, 2001; Polyakov and Kharlashina, 1995), and CO in this equilibrium is much more depleted in the heavy ${ }^{13} \mathrm{C}$ isotope relative to $\mathrm{CO}_{2}$ than graphite is (Fig. 5). At temperatures of $500-200^{\circ} \mathrm{C}$, the equilibrium isotope shift between $\mathrm{CO}_{2}$ and $\mathrm{CO}$ varies from 18 to $40 \%$. The further kinetic isotopic effect during $\mathrm{CO}$ disproportionation can also slightly increase the overall depletion of the newly formed graphite in the ${ }^{13} \mathrm{C}$ heavy isotope, whereas the dominant effect occurs when $\mathrm{CO}_{2}$ occurs in equilibrium with $\mathrm{CO}$ in the gas phase. At temperatures of $500-300^{\circ} \mathrm{C}$, the isotope shift between $\mathrm{CO}_{2}$ and $\mathrm{CO}$ varies from 18.0 to $29.6 \%$, which ensures, under the assumption of equilibrium with magmatic $\mathrm{CO}_{2}\left(\delta^{13} \mathrm{C} \approx-6 \pm 2 \%\right.$ ) , the depletion of the reduced carbon to the observed values of $\delta^{13} \mathrm{C}<-20 \%$ o (Fig. 2; Martinez et al., 2021), with that occurring at the lower temperature limit even at a relatively high percentage of $\mathrm{CO}_{2}$ conversion. The mechanism of the origin of the reduced carbon according to the BellBoudouard reaction is thus consistent with the model (Shilobreeva et al., 2011), according to which this process occurs near the ridge axis during the early production of the oceanic crust and then does not any significantly change in the course of its further changes.

An abiogenic origin of the reduced component of the dispersed carbon is best consistent with its concentrations and isotope composition found in the basalt

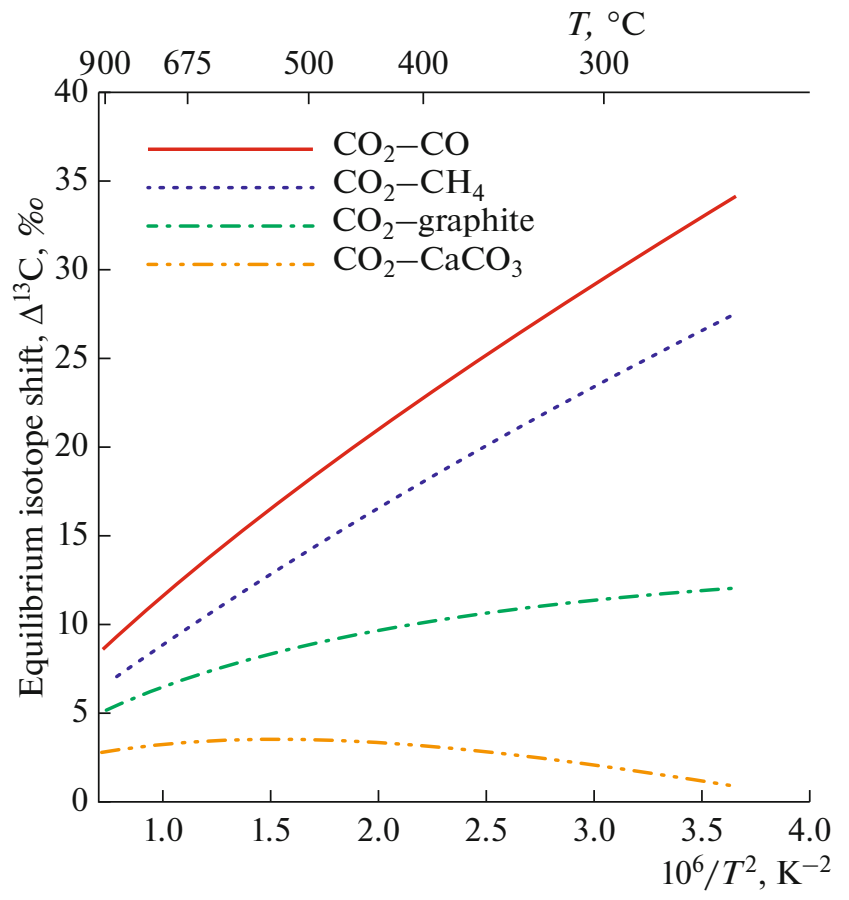

Fig. 5. Temperature dependence of equilibrium carbon isotope fractionation between $\mathrm{CO}_{2}$ and some carbon-bearing compounds. The equilibrium shift between the carbon-bearing compounds was calculated from the $\beta$-factors of carbon by the formula $\Delta_{\mathrm{A}-\mathrm{B}}(\% o) \approx 1000\left(\ln \beta_{\mathrm{A}}-\ln \beta_{\mathrm{B}}\right)$, where $\beta$ is the $\beta$-factor, and the indices $A$ and $B$ denote carbon-bearing compounds between which the isotopic shift was calculated. The $\beta$-factors for $\mathrm{CO}_{2}$, calcite, and graphite are taken from (Mironenko et al., 2018) and those for CO from (Richet et al., 1977).

groundmass in samples from Holes $801 \mathrm{C}$ and $1256 \mathrm{D}$. At high temperatures $\left(>350^{\circ} \mathrm{C}\right)$, the mechanisms based on the Bell-Boudouard reaction seems to be dominant, whereas the Fischer-Tropsch process likely becomes more efficient at temperatures below $250-300^{\circ} \mathrm{C}$.

\section{Implications for the Carbon Cycle}

Dispersed carbon in the basalt groundmass of the altered oceanic crust in Holes 801C and 1256D is of magmatic genesis, except only UVZ in the ancient oceanic crust (Hole 801C). The oxidized component of the dispersed carbon is the residual carbon after $\mathrm{CO}_{2}$ degassing, which is dissolved in the magmatic melt. The reduced component of the dispersed carbon is elemental carbon, which is generated on the newly formed crystal surfaces during rock alterations by the Bell-Boudouard reaction from the degassed $\mathrm{CO}_{2}$ and/or from organic compounds according to the Fischer-Tropsch synthesis. The aforementioned data on Hole $1256 \mathrm{D}$ make it possible to evaluate the concentration and isotope composition of dispersed car- 
bon of magmatic origin in the basaltic basement of the altered oceanic crust. ${ }^{4}$

The results of such estimates have been obtained by the method suggested in (Alt and Teagle, 1999) for the part of the basaltic basement drilled-through by Hole $1256 \mathrm{D}$ and are presented in Table 1. The concentration of magmatic dispersed carbon in the penetrated vertical section of the basaltic basement is $0.144 \pm$ $0.061 \mathrm{wt} \% \mathrm{CO}_{2}$, and its $\delta^{13} \mathrm{C}=-22.2 \pm 2.1 \%$. The average total carbon concentration in the whole oceanic crust can be estimated for the upper part of the basement of the same thickness using data on carbon concentrations in the lithological zones (Alt and Teagle, 1999). This estimate corresponds to $0.668 \mathrm{wt} \%$ $\mathrm{CO}_{2}$. Hence, the percentage of magmatic dispersed carbon in the total carbon concentration in the drilled-through part of the basaltic basement is close to $21.8 \pm 8.1 \%$. Hole $1256 \mathrm{D}$ penetrated only the uppermost $100 \mathrm{~m}$ of the 5 -km gabbro zone. Hence, the total carbon concentration and $\delta^{13} \mathrm{C}$ reported in Table 1 cannot be extended to the whole gabbro zone. If the estimated value of $0.05 \mathrm{wt} \% \mathrm{CO}_{2}$ is assumed for dispersed carbon in the lower portion of the gabbro zone (Alt and Teagle, 1999), then the average concentration of magmatic dispersed carbon in the whole altered oceanic crust is $0.059 \pm 0.030 \mathrm{wt} \% \mathrm{CO}_{2}$. Comparison of this value with $0.21 \mathrm{wt} \% \mathrm{CO}_{2}$ as the average concentration of total carbon in the oceanic crust (Alt and Teagle, 1999) leads to the conclusion that magmatic dispersed carbon makes up $28 \pm 14 \%$ of the total carbon concentration contained in the altered oceanic basaltic crust. Obviously, the fraction of magmatic dispersed carbon decreases with increasing content of veins, halos, cavities, etc. in the basaltic oceanic crust, with intensified infiltration of seawater-dissolved carbonate and organic carbon through the basalt groundmass, and with increasing microbial activity. It is also obvious that these processes were more intense in the ancient than in the young crust. Because of this, the percentage of magmatic dispersed carbon in hole drilled through younger rocks may be much higher than the average estimates presented above.

Based on these estimates, we can compare the flow of magmatic dispersed carbon coming to the oceanic crust with the carbon flow coming to the atmosphere with the gas phase in the zones where basaltic oceanic crust is produced. The growth rate of the oceanic crust is $6.0 \pm 0.8 \times 10^{16} \mathrm{~g} /$ year (Mottl, 2003). With regard to the aforementioned estimates, this leads to $8.1 \pm 4.2 \times$ $10^{11} \mathrm{~mol} \mathrm{C} /$ year. Estimates of the carbon flow through the gas phase also broadly vary, from $2.0 \times 10^{12}$ to $2.0 \times 10^{12} \mathrm{~mol} \mathrm{C} /$ year (Javoy et al., 1982; Des Marais, 1985; Javoy and Pineau, 1991; Marty and Tolstikhin, 1998; Cartigny et al., 2001, 2008). These broad variations in the estimated carbon flow through the gas

\footnotetext{
${ }^{4}$ Data on Hole $801 \mathrm{C}$ pertain only to the volcanic zone and are insufficient for such estimates.
}

phase lead, of course, to a large uncertainty in estimates of the percentage of dispersed carbon in the altered basaltic oceanic crust and in those of the total carbon flow coming from magmatic melts in the zone where the basaltic oceanic crust is formed. This percentage varies from 2 to $38 \%$. A small fraction ( 10$15 \%)$ of the magmatic carbon flow through the solid phase is in good agreement with the enrichment of reduced magmatic carbon up to $\delta^{13} \mathrm{C}<-20 \%$ due to the Bell-Boudouard or Fischer-Tropsch reactions.

\section{CONCLUSIONS}

Our analysis of the concentration and isotope composition of oxidized carbon in basalt groundmass samples from Hole 801C shows that oxidized carbon of these samples is of different genesis. Oxidized carbon in samples in which carbonates were found is characterized by $\delta^{13} \mathrm{C}=0 \pm 1.5 \%$ (Fig. 2) and represents precipitated seawater DIC.

Oxidized carbon in the samples, which do not contain any carbonate phase, is characterized by low $\mathrm{CO}_{2}$ concentrations of $<0.1 \mathrm{wt} \%$ and $\delta^{13} \mathrm{C}<-6 \%$. The concentrations and isotope composition of this oxidized carbon lie within the same ranges as those of carbon dissolved in the basalt glasses of mid-oceanic ridges and oceanic islands (Fig. 3), which indicates that they have a common genesis. Oxidized carbon in these samples (and in the basalt glasses as well) is residual after $\mathrm{CO}_{2}$ degassing and was dissolved in the magmatic melt in the form of $\mathrm{CO}_{3}^{2-}$ groups.

It is shown that the positive correlation between total carbon content and its isotope composition at presence of the carbonate phase in basalt groundmass samples can be considered as a criterion of infiltration of carbonates precipitated from seawater into the basalt groundmass. The application of this criterion to basalt groundmass samples from the young oceanic crust ( $\sim 15 \mathrm{Ma}$, Hole $1256 \mathrm{D})$ shows that no infiltration of carbonate carbon took place and that the oxidized component of the dispersed carbon is residual magmatic carbon after $\mathrm{CO}_{2}$ degassing.

Models of a biogenic origin of reduced dispersed carbon fail to reasonably accurately describe profiles of carbon concentrations and its isotope composition in basalt groundmass samples from Holes $801 \mathrm{C}$ and $1256 \mathrm{D}$. The very small variations in the concentrations and isotope composition of the reduced dispersed carbon with depth are most adequately described by the model of the abiogenic synthesis of carbon near the ridge axis at high temperatures.

It is demonstrated that the mechanism (Mathez and Delaney, 1981) forming reduced dispersed carbon on newly formed crystal surfaces of minerals by the Bell-Boudouard reaction is able to enrich the newly formed elemental carbon in the ${ }^{12} \mathrm{C}$ isotope up to 
$\delta^{13} \mathrm{C}<-20 \%$ due to isotope fractionation at $\mathrm{CO}_{2}-$ $\mathrm{CO}$ equilibrium in the gas phase.

Available data are used to estimate the fraction of magmatic carbon contained in the altered basaltic oceanic crust. According to this estimate, $28 \pm 14 \%$ of the total carbon amount stored in the basaltic oceanic crust is magmatic carbon. Correspondingly, the estimates of the flow of magmatic carbon through the condensed basaltic crust are $8.1 \pm 4.2 \times 10^{11} \mathrm{~mol} \mathrm{C} /$ year, which corresponds to 2 to $38 \%$ of total flow of magmatic carbon.

The models presented herein for an abiogenic genesis of dispersed carbon enriched in the light isotope in the basalt groundmass do not require the presence of carbon with low $\delta^{13} \mathrm{C}$ in the magmatic melt. The residual oxidized dispersed carbon becomes enriched in the ${ }^{12} \mathrm{C}$ light isotope $\left(-15 \% \circ<\delta^{13} \mathrm{C}<-7 \%\right.$ ) when the mantle melt degasses, whereas the reduced carbon is enriched in the ${ }^{12} \mathrm{C}$ isotope in the course of postmagmatic alterations of the basaltic oceanic crust by means of the formation of elemental dispersed carbon on fresh mineral surfaces according to the BellBoudouard reaction and/or synthesis of organic compounds by the Fischer-Tropsch process.

\section{ACKNOWLEDGMENTS}

The authors thank their colleagues Dr. Isabelle Martinez, Prof. Jeffrey C. Alt, and Prof. Pierre Agrinier for longlasting fruitful discussions. S.N. Shilobreeva thanks her French colleagues Isabelle Martinez and Pierre Agrinier for inviting her to Université de Paris, Institut de physique du globe de Paris, CNRS, and providing her with the possibility of conducting the experiments. The authors thank corresponding member of the Russian Academy of Sciences E.O. Dubinina and Dr. S.A. Silantyev for constructive and benevolent criticism and comments, which were very useful and led us to improve the text of the manuscript.

\section{FUNDING}

This study was carried out under government-financed research program 0137-2019-0015 for Vernadsky Institute of Geochemistry and Analytical Chemistry (GEOKhI), Russian Academy of Sciences.

\section{OPEN ACCESS}

This article is licensed under a Creative Commons Attribution 4.0 International License, which permits use, sharing, adaptation, distribution and reproduction in any medium or format, as long as you give appropriate credit to the original author(s) and the source, provide a link to the Creative Commons license, and indicate if changes were made. The images or other third party material in this article are included in the article's Creative Commons license, unless indicated otherwise in a credit line to the material. If material is not included in the article's Creative Commons license and your intended use is not permitted by statutory regulation or exceeds the permitted use, you will need to obtain permission directly from the copyright holder. To view a copy of this license, visit http://creativecommons.org/licenses/by/4.0/.

\section{REFERENCES}

Alt, J.C., Stable isotopic composition of upper oceanic crust formed at a fast spreading ridge, ODP Site 801, Geochem. Geophys. Geosyst., 2003, vol. 4, no. 5, p. Q8908.

https://doi.org/10.1029/2002GC000400

Alt, J.C. and Teagle, D.A.H., The uptake of carbon during alteration of ocean crust, Geochim. Cosmochim. Acta, 1999, vol. 63, pp. 1527-1535.

Alt, J.C. and Shank, W.C., Microbial sulfate reduction and the sulfur budget for a complete section of altered oceanic basalts, IODP Hole 1256d (eastern pacific), Earth Planet. Sci. Lett., 2011, vol. 310, pp. 73-83.

Alt, J.C. and Teagle, D.A.H., Hydrothermal alteration of upper oceanic crust formed at fast spreading ridge: mineral, chemical, and isotopic evidence from ODP Site 801, Chem. Geol., 2003, vol. 201, pp. 191-211.

Alt, J.C., Davidson, G.J., Teagle, D.A.H., and Karson, J.A., Isotopic composition of gypsum in the Macquarie Island ophiolite: implications for the sulfur cycle and the subsurface biosphere in oceanic crust, Geology, 2003, vol. 31, pp. 549-552.

Alt, J.C., Laverne, C., Coggon, R.M., et al., Subsurface structure of a submarine hydrothermal system in ocean crust formed at the East Pacific Rise, ODP/IODP Site 1256, Geochem. Geophys. Geosyst., 2010, vol. 11, p. Q10010. Alt, J.C., Schwarzenbach, E.M., Fruh-Green, G.L., et al., The role of serpentinites in cycling of carbon and sulfur: seafloor serpentinization and subdurction metamorphism, Lithos. 2013, vol. 178, pp. 40-54.

https://doi.org/10.1016/j.lithos.2012.12

Aubaud, C., Pineau, F., Jambon, A., and Javoy, M., Kinetic disequilibrium of $\mathrm{C}, \mathrm{He}, \mathrm{Ar}$ and carbon isotopes during degassing of mid-ocean ridge basalts, Earth Planet. Sci. Lett., 2004, vol. 222, pp. 391-406.

Blank, J.G., Delaney, J.R., and Des, MaraisD.J., The concentration and isotopic composition of carbon in basaltic glasses from the Juan de Fuca Ridge, Pacific Ocean, Geochim. Cosmochim. Acta, 1993, vol. 57, pp. 875-887.

Bottinga, Y., Carbon isotope fractionation between graphite, diamond and carbon dioxide, Earth Planet. Sci. Lett., 1969 , vol. 5, pp. 301-306.

Cartigny, P., Stable isotopes and the origin of diamond, Elements, 2005, vol. 1, no. 2, pp. 79-84.

Cartigny, P., Jendrzejewski, N., Pineau, F., et al., Volatile (C, N, Ar) variability in MORB and the respective roles of mantle source heterogeneity and degassing: the case of the southwest Indian Ridge, Earth Planet. Sci. Lett., 2001, vol. 194, pp. 241-257.

Cartigny, P., Pineau, F., Aubaud, C., and Javoy, M., Towards a consistent mantle carbon flux estimate: insights from volatile systematics $\left(\mathrm{H}_{2} \mathrm{O} / \mathrm{Ce}, \delta \mathrm{D}, \mathrm{CO}_{2} / \mathrm{Nb}\right)$ in the North Atlantic mantle $\left(14^{\circ} \mathrm{N}\right.$ and $\left.34^{\circ} \mathrm{N}\right)$, Earth Planet. Sci. Lett., 2008, vol. 265, pp. 672-685.

Cartigny, P., Palot, M., Thomassot, E., and Harris, J.W., Diamond formation: a stable isotope perspective, Ann. Rev. Earth Planet. Sci., 2014, vol. 42, pp. 699-732.

Chacko, T., Mayeda, T.K., Clayton, R.N., and Goldsmith, J.R., Oxygen and carbon isotope fractionation be- 
tween $\mathrm{CO}_{2}$ and calcite, Geochim. Cosmochim. Acta, 1991, vol. 55, pp. 2867-2882.

Chacko, T., Cole, D.R., and Horita, J., Equilibrium oxygen, hydrogen and carbon isotope fractionation factors applicable to geologic systems, Rev. Mineral. Geochem., 2001, vol. 43, pp. 1-81.

Craig, H., The geochemistry of the stable carbon isotopes, Geochim. Cosmochim. Acta, 1953, vol. 3, pp. 53-92.

Deines, P. and Eggler, D.H., Experimental determination of carbon isotope fractionation between $\mathrm{CaCO}_{3}$ and graphite, Geochim. Cosmochim. Acta, 2009, vol. 73, pp. 72567274.

Delacour, A., Früh-Green, G.L., Bernasconi, S.M., et al., Carbon geochemistry of serpentinites in the Lost City hydrothermal system ( $30^{\circ} \mathrm{M}$, MAR), Geochim. Cosmochim. Acta, 2008, vol. 72, pp. 3681-3702.

Des Marais, D.J., Carbon exchange between the mantle and the crust, and its effect upon the atmosphere: Today compared to Archean time, The Carbon Cycle and Atmospheric $\mathrm{CO}_{2}$ : Natural Variations, Archean to Present, Sundquist, E.T. and Broecker, W.S., Eds., AGU Geophys. Monogr., 1985, vol. 32, pp. 602-611.

https://doi.org/10.1029/GM032p0602

Des Marais, D.J. and Moore, J.G., Carbon and its isotopes in mid-oceanic basaltic glasses, Earth Planet. Sci. Lett., 1984, vol. 5, pp. 43-57.

Freund, F., Mechanism of the water and carbon dioxide solubility in oxides and silicates and the role of $\mathrm{O}^{-}$, Contrib. Mineral. Petrol., 1981, vol. 76, pp. 474-482.

Freund, F., Hydrogen and carbon in solid solution in oxides and silicates, Phys. Chem. Mineral., 1987, vol. 15, pp. 1-18. Freund, F., Debras, G., and Demortier, G., Carbon content of magnesium oxide single crystals grown by the arc fusion method, J. Cryst. Growth, 1977, vol. 38, pp. 277-80.

Freund, F., Debras, G., and Demortier, G., Carbon content of high-purity alkaline earth oxide single crystals grown by arc fusion, J. Am. Ceram. Soc., 1978, vol. 61, pp. 429434.

Freund, F., Kathrein, H.W., Knobel, H.R., and Heinen, H.J., Carbon in solid solution in forsterite; a key to the untracable nature of reduced carbon in terrestrial and cosmogenic rocks, Geochim. Cosmochim. Acta, 1980, vol. 44, pp. 13191334.

Früh-Green, G.L., Connolly, J.A.D., Plas, A., et al., Serpentinization of oceanic peridotites: implications for geochemical cycles and biological activity, The Subseafloor Biosphere at MORs. AGU Geophys. Monogr. Ser., 2004, vol. 144, pp. 119-136.

Galimov, E.M., Geokhimiya stabil'nykh izotopov ugleroda (Geochemistry of Stable Carbon Isotopes), Moscow: Nedra, 1968.

Galimov, E.M., Variations of isotope composition of diamonds and their relation with conditions of diamond formation, Geokhimiya, 1984, no. 8, pp. 1091-1117.

Galimov, E.M., Isotope fractionation related to kimberlite magmatism and diamond formation, Geochim. Cosmochim. Acta, 1991, vol. 55, pp. 1697-1708.

Haas, L.A., Khalafalla, S.E., and Weston, Jr, P.L., Kinetics of formation of carbon dioxide and carbon from carbon monoxide in presence of iron pellets, U.S. Bur. Mines. Dep. Invest., 1968, pp. 7064-7092.

Hoefs, J., Stable Isotope Geochemistry, Springer International Publishing, 2018.

Jarrard, R.D., Abrams, L.J., Pockalny, R., et al., Physical properties of upper oceanic crust: Ocean Drilling Program
Hole $801 \mathrm{C}$ and the waning of hydrothermal circulation, $J$. Geophys. Res., 2003, vol. 108, no. B4, p. 2188.

Javoy, M. and Pineau, F., The volatile record of a "popping" rock from the Mid-Atlantic Ridge at $14^{\circ} \mathrm{N}$ : chemical and isotopic composition of gas trapped in the vesicles, Earth Planet. Sci. Lett., 1991, vol. 107, pp. 598-611.

Javoy, M., Pineau, F., and Allegre, C., The carbon geodynamic cycle, Nature, 1982, vol. 300, pp. 171-173.

Kadik, A.A., Pineau, F., Litvin, Y.A., et al., Formation of carbon and hydrogen species in magmas at low oxygen fugacity during fluid-absent melting of carbon-bearing mantle, J. Petrol., 2004, vol. 45, pp. 1297-1310.

Kathrein H., Gonska, H. and Freund, F., Subsurface segregation and diffusion of carbon in magnesium oxide, Appl. Phys., 1983, vol. 30, pp. 33-41.

Keppler, H., Wiedenbeck, M., and Shcheka, S.S., Carbon solubility in olivine and the mode of carbon storage in the earth's mantle, Nature, 2003, vol. 424, pp. 414-416.

Kitchen, N.E. and Valley, J.M., Carbon isotope thermometry in marbles of the Andirondack mountains, New York, J. Metamorph. Geol., 1995, vol. 13, pp. 577-594

Lancelot, Y., Larson, R.L., and Fisher, A., Ocean Drilling Program Leg 129 preliminary report: old Pacific crust, Proc. Ocean Drill. Program Sci. Results, 1990, vol. 129, pp. 1-28.

Lapidus, A.L., Eliseev, O.L., and Kryuchkov, M.V., BellBoudoir and water gas shift reactions under conditions of the Fischer-Tropsch synthesis, Solid Fuel Chem., 2011, vol. 45, pp. 313-314.

https://doi.org/10.3103/S0361521911050041

Mathez E.A., Delaney, J.R., The nature and distribution of carbon in submarine basalts and peridotite nodules, Earth Planet. Sci. Lett., 1981, vol. 56, pp. 217-232.

Martinez, I., Shilobreeva S.N., Alt J. et al. The origin and fate of $\mathrm{C}$ during alteration of the oceanic crust, Inst. de France. Academie des Scienses. Les Comptes Rendus-Géoscience, 2021, vol. 323, pp. 319-336.

https://doi.org/10.5802/crgeos.61

Marty, B. and Tolstikhin, I.N., $\mathrm{CO}_{2}$ fluxes from MORs, arcs and plumes, Chem. Geol., 1998, vol. 145, pp. 233-248. Mathez, E.A., Influence of degassing on oxidation states of basaltic magmas, Nature, 1984, vol. 310, pp. 371-375.

Mathez, E.A., Carbonaceous matter in mantle xenoliths: composition and relevance to the isotopes, Geochim. Cosmochim. Acta, 1987, vol. 51, pp. 2339-2347.

Mathez, E.A. and Mogk, D.M., Characterization of carbon compounds on a pyroxene surface from a gabbro xenolith in basalt by time-of-flight secondary ion mass spectrometry, Am. Mineral., 1998, vol. 83, pp. 918-924.

Mathez, E.A., Roberts, J.J., Duba, A.G., et al., Carbon deposition during brettle rock. deformation: changes in electrical propertes of fault zones and potential geoelectric phenomena during earthquakes, J. Geophys. Res., 2008, vol. 113, p. B12201.

Mattey, D.P., Carr, R.H., Wright, I.P., and Pillinger, C.T., Carbon isotopes in submarine basalts, Earth Planet. Sci. Lett., 1984, vol. 70, pp. 196-206.

Mattey, D.P., Exley, R.A., and Pillinger, C.T., Isotopic composition of $\mathrm{CO}_{2}$ and dissolved carbon species in basalt glass, Geochim. Cosmochim. Acta, 1989, vol. 53, pp. 23772386 .

McCollom, T. and Seewald, J.S., Carbon isotope composition of organic compounds produced by abiotic synthesis under hydrothermal conditions, Earth Planet. Sci. Lett., 2006, vol. 243, pp. 74-84. 
McCollom, T. and Seewald, J.S., Abiotic synthesis of organic compounds in deep-sea hydrothermal environments, Chem. Rev., 2007, vol. 107, pp. 382-401.

McCollom, T. and Bach, W., Thermodynamic constraints on hydrogen generation during serpentinization of ultramafic rocks, Geochim. Cosmochim. Acta, 2009, vol. 73, pp. 856-875.

McCrea, J.M., On the isotopic chemistry of carbonates and a paleotemperature scale, J. Chem. Phys., 1950, vol. 18, pp. 849-857.

Menez, B., Pasini, V., and Brunelli, D., Life in the hydrated suboceanic mantle, Nature Geosci., 2012, vol. 5, no. 2, pp. $133-137$.

Mironenko, M.V., Polyakov, V.B., and Alenina, M.V., Simultaneous calculation of chemical and isotope equilibria using the GEOCHEQ isotope software: carbon isotopes, Geochem. Int., 2018, vol. 56, pp. 1354-1367.

Mottl, M.J., Partitioning of energy and mass fluxes between MOR axes at high and low temperature, Energy and Mass Transfer in Marine Hydrothermal Systems, Halbach, P.E., Eds., Dahlem University Press, 2003, pp. 271-286.

Ni, H. and Keppler, H., Carbon in silicate melts, Rev. Mineral. Geochem., 2013, vol. 75, pp. 251-287.

Olsson, R.G. and Turkdogan, E.T., Catalytic effect of iron on decomposition of carbon monoxide. II. Effect of additions of $\mathrm{H}_{2}, \mathrm{H}_{2} \mathrm{O}, \mathrm{CO}_{2}, \mathrm{SO}_{2}$ and $\mathrm{H}_{2} \mathrm{~S}$, Metall. Trans. A, 1974, vol. 5, pp. 21-26.

Pineau, F. and Mathez, E.A., Carbon isotopes in xenoliths from the Hualalai Volcano, Hawaii, and the generation of isotopic variability, Geochim. Cosmochim. Acta, 1990, vol. 54, pp. 211-227.

Pineau, F., Shilobreeva, S., Hekinian, R., et al., Deep-sea explosive activity on the Mid-Atlantic Ridge near $34^{\circ} 50^{\prime} \mathrm{N}$ : a stable isotope (C, H, O) study, Chem. Geol., 2004, vol. 211, pp. 159-175.

Plank, T., Ludden, J.N., and Escutia, C., Leg 185: 3. Site 801, Proceedings of the Ocean Drilling Program. Initial Reports, 2000, vol. 185 .

https://doi.org/10.2973/odp.proc.ir.185.2000

Polyakov, V.B. and Kharlashina, N.N., The use of heat capacity data to calculate carbon isotope fractionation between graphite, diamond, and carbon dioxide: a new approach, Geochim. Cosmochim. Acta, 1995, vol. 59, pp. 2561-2572.

Renshaw, G.D., Roscoe, C., and Walker, P.L., Jr. Disproportionation of CO: I. Over iron and silicon-iron single crystals, J. Catal., 1970, vol. 18, pp. 164-183.

Rhusdi, A.I. and Simoneit, B.T., Lipid formation by aqueous Fischer-Tropsch-type synthesis over a temperature range of 100 to $400^{\circ} \mathrm{C}$, Origins of Life and Evolution of the Biosphere, 2001, vol. 31, pp. 103-118.

Richet, P., Bottinga, Y., and Javoy, M., A review of hydrogen, carbon, nitrogen, oxygen, suphur and chlorine stable isotope fractionation among gaseous molecules, Ann. Rev. Earth Planet. Sci., 1977, vol. 5, pp. 65-110.

Rouxel, O., Ono, S., Alt, J., et al., Sulfur isotope evidence for microbial sulfate reduction in alteredoceanic basalts at ODP Site 801, Earth Planet. Sci. Lett., 2008, vol. 268, pp. 110-123.

Sakai, H., Des, MaraisD.J., Ueda, A., and Moore, J.G., Concentrations and isotope ratios of carbon, nitrogen and sulfur in ocean-floor basalts, Geochim. Cosmochim. Acta, 1984, vol. 48, pp. 2433-2441.

Seewald, J.S., Zolotov, M.Y., and McCollom, T., Experimental investigation of single carbon compounds under hy- drothermal conditions, Geochim. Cosmochim. Acta, 2006, vol. 70, pp. 446-460.

Shcheka, S.S., Wiedenbeck, M., Frost, D., and Keppler, H., Carbon solubility in mantle minerals, Earth Planet. Sci. Lett., 2006, vol. 245, pp. 730-742.

Shilobreeva, S., Martinez, I., Busigny, V., et al., Insights into $\mathrm{C}$ and $\mathrm{H}$ storage in the altered oceanic crust: results from ODP/IODP Hole 1256D, Geochim. Cosmochim. Acta, 2011, vol. 75, pp. 2237-2255.

Shipboard Scientific Party Site 1256, Proc. ODP, Init. Repts., 206: College Station, TX (Ocean Drilling Program), Wilson, D.S. Teagle, D.A.H., and Teagle, G.D., Eds., Acton, 2003.

https://doi.org/10.2973/odp.proc.ir.206.103.2003

Shock, L.E., Geochemical constraints on the origin of organic compounds in hydrothermal systems, Origins of Life and Evolution of the Biosphere, 1990, vol. 20, pp. 331-367.

Shock, L.E. and Schulte, M.D., Organic synthesis during fluid mixing in hydrothermal systems, J. Geophys. Res., 1998, vol. 103, pp. 28513-28527.

Taran, Y.A., Kliger, G.A., and Sevastianov, V.S., Carbon isotope effects in the open-system Fischer-Tropsch synthesis, Geochim. Cosmochim. Acta, 2007, vol. 71, pp. 4474-4487.

Taran, Y.A., Kliger, G.A., Cienfuegos, E., and Shuykin, A.N., Carbon and hydrogen isotopic compositions of products of open-system catalytic hydrogenation of $\mathrm{CO}_{2}$ : implications for abiogenic hydrocarbons in earth's crust, Geochim. Cosmochim. Acta, 2010, vol. 74, pp. 6112-6125.

Teagle, D.A.H., Alt, J.C., Umino, S., et al., Superfast spreading rate crust 2 and 3, Integrated Ocean Drilling Program Management International, 2006, vol. 309/312, p. 50. https://doi.org/10.2204/iodp.-proc.309312.2006

Tingle, T.N. and Green, H.W., Carbon solubility in olivine: implications for upper mantle evolution, Geology, 1987, vol. 15 , pp. $324-326$.

Tingle, T.N. and Hochella, M.F., Formation of reduced carbonaceous matter in basalts and xenoliths: reaction of $\mathrm{C}-\mathrm{O}-\mathrm{H}$ gases on olivine crack surfaces, Geochim. Cosmochim. Acta, 1993, vol. 57, pp. 3245-3249.

Tingle, T.N., Green, H.W., and Finnerty, A.A., Experiments and observations bearing on the solubility and diffusivity of carbon in olivine, J. Geophys. Res., 1988, vol. 93, pp. 15289-15304.

Trofimov, A.V., Relations of carbon isotopes in meteorites, Dokl. Akad. Nauk SSSR, 1950, vol. 72, no. 4, pp. 663-666. Trofimov, A.V., Carbon isotope composition of magmatic rocks, Dokl. Akad. Nauk SSSR, 1952, vol. 85, no. 1, pp. 169-172.

Tsao, T.C., Kun Li, and Philbrook, W.O., Kinetics of dissociation of carbon monoxide on $\alpha$-iron, Can. Metallurg. Quarterly, 1977, vol. 16, pp. 93-103.

Turkdogan, E.T. and Vinters, J.V., Catalytic effect of iron on decomposition of carbon monoxide: I. Carbon deposition in H2-CO mixtures, Metall. Trans. A, 1974, vol. 5, pp. 11-20.

Vinogradov, A.P., Isotope composition of rocks of Earth and meteorites, Atom. Energiya, 1958, vol. 5, no. 4, pp. 409-416.

Vinogradov, A.P., Khimicheskaya evolyutsiya Zemli (Chemical Evolution of the Earth), Moscow: Izd-vo AN SSSR, 1959.

Wengeler, H., Knobel, R., Katherin, H., et al., Atomic carbon in magnesium oxide single crystals - depth profiling? Temperature- and time-dependent behavior, J. Phys. Chem. Solids, 1982, vol. 43, p. 5971.

Translated by E. Kurdyukov 